\title{
Badania istotności wpływu podstawowych parametrów napawania plazmowego na geometrię napoin
}

\author{
Study significance of the impact of the basic parameters \\ of plasma surfacing on the geometry of the weld overlays
}

\section{Streszczenie}

W oparciu o metody planowania eksperymentu przedstawiono wpływ głównych parametrów napawania plazmowego proszkowego na geometrię napoin. Eksperyment wykonano na podstawie matrycy planu Placketta-Burmana a matematyczne opracowanie wyników badań w oparciu o metodę bilansu losowego. W efekcie wyznaczono parametry napawania plazmowego, które istotnie wpływają na geometrię powłok i udział metalu podłoża w napoinie. Wykazano, iż występuje zróżnicowanie wpływu parametrów procesu napawania na mierzone wielkości.

Słowa kluczowe: napawanie plazmowe, napoina, planowanie eksperymentu

\begin{abstract}
The influence of the main parameters of plasma powder transferred arc welding on the geometry of the weld overlays is presented in the paper based on the Design of Experiment methods. The matrix experiments was planned according to the Plackett-Burman plan whereas research data handling was based on random balance method. As a result, plasma welding parameters which significantly influence the geometry of the coating and its dilution was determined. It has been shown that particular surfacing parameters have different impact onto measured values.
\end{abstract}

Keywords: plasma surfacing, weld overlays, design of experiment

\section{Wstęp}

Napawanie plazmowe proszkowe (ang. PPTAW Plasma Powder Transferred Arc Welding) obok napawania laserowego i wiązką elektronów należy do wysokoenergetycznych technik stosowanych w modyfikacji bądź regeneracji warstwy wierzchniej. Niższy koszt urządzeń oraz wyższa wydajność w porównaniu do powyższych dwóch metod czyni napawanie plazmowe wciąż bardzo atrakcyjną metodę nanoszenia powłok o szczególnych własnościach. Zastosowanie materiału dodatkowego w postaci proszku umożliwia otrzymywanie powłok o szerokim zakresie składu chemicznego, w tym napoin o strukturze materiału kom-

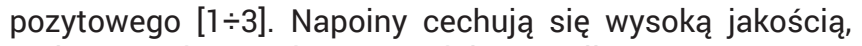
małym rozcieńczeniem materiałem podłoża oraz stosunkowo niewielką strefą wpływu ciepła. Stąd wynikają liczne

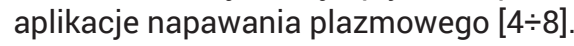

Istotną cechą tej metody jest także duża liczba parametrów procesowych. Z jednej strony umożliwia to sterowanie procesem napawania w szerokim zakresie, od napawania wąskich, o małej wysokości ściegów, do bardzo szerokich i o dużym nadlewie. Z drugiej strony trudno jest dobrać odpowiednie wartości parametrów warunkujących otrzymywanie powłok o żądanej geometrii czy też cechach użytkowych. Toteż w opracowaniu technologii napawania niezbędna jest praktyczna wiedza inżynierska, która dodatkowo może być wspomagana statystycznymi metodami planowania eksperymentu (ang. DOE Design of Experiments). Zastosowanie metod planowania eksperymentu na etapie doboru parametrów procesu znacząco ogranicza liczbę prób, a co za tym idzie nakłady finansowe i oszczędność czasu.

Zagadnienia podstawowe planowania eksperymentu są wyczerpująco omawiane w rodzimej literaturze, np. w pozy-

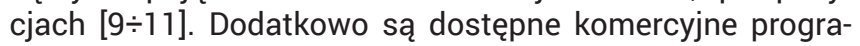
my wspomagające planowanie i statystyczne opracowanie wyników badań, np. STATISTICA, Design-Expert, CADEX, PLANEKS-STAT. Mimo to, w krajowej literaturze spotykane są nieliczne prace z zakresu inżynierii spajania, w których stosowano metody planowania eksperymentu [12:15]. Opracowania dotyczących procesu napawania plazmowego w których stosowano narzędzia planowania eksperymentu można znaleźć jedynie w literaturze światowej. W publika-

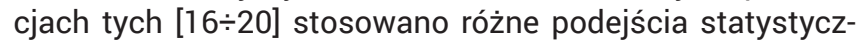
ne na podstawie których tworzono model matematyczny wpływu parametrów napawania na właściwości powłok napawanych i ich kształt. Do badań przyjmowano parametry i ich zakresy bez statystycznej weryfikacji istotności wpływu a jedynie na podstawie analizy literatury.

W niniejszej pracy przedstawiono badania wpływu głównych parametrów napawania plazmowego na geometrię napoin i udział metalu podłoża w napoinie. Na podstawie tych badań uszeregowano parametry napawania mające

Dr inż. Mariusz Bober, inż Konrad Tobota - Zakład Inżynierii Spajania, Politechnika Warszawska. 
istotny wpływ na: wysokość nadlewu, szerokość lica, głębokość wtopienia i udział metalu podłoża w napoinie. Badania te przeprowadzono w oparciu o statystyczne plany badania istotności wpływu [21].

\section{Stosowane materiały}

Badania zostały wykonane dla układu stal niestopowa - napoiny na bazie niklu. Materiał dodatkowy do napawania stanowił typowy proszek do napawania na osnowie niklu, produkcji jednej z czołowych firm światowych. Skład chemiczny tego proszku przedstawiono $\mathrm{w}$ tabeli I. Ziarnistość tego proszku zawierała się w przedziale 50-150 $\mu \mathrm{m}$.

Jako materiał podłoża zastosowano stal niestopową o symbolu S235JR. Do badań przygotowano próbki o wymiarach 10x50x150 mm. Przed procesem napawania powierzchnia stalowych podłoży była piaskowana i odtłuszczana.

Przed wykonaniem właściwej serii prób przeprowadzono badania wstępne mające na celu określenie pozostałych, stałych parametrów procesu.

Tablica I. Skład chemiczny proszku, wg atestu producenta Table I. The chemical composition of the powder, according to manufacturer's certificate

\begin{tabular}{|c|c|c|c|c|}
\hline \multicolumn{7}{|c|}{ Zawartość pierwiastków, \% wag. } \\
\hline Si & B & C & Fe & Ni \\
\hline 2,5 & 1,4 & $\leq 0,05$ & $\leq 1$ & reszta \\
\hline
\end{tabular}

\section{Metodyka badań}

W celu określenia istotności głównych parametrów napwania plazmowego na geometrię i udział metalu podłoża w napoinach przyjęto następujący program badań:

- Identyfikacja głównych parametrów procesu i ustalenie zakresu ich zmienności,

- Dobór planu eksperymentu,

- Opracowanie matrycy doświadczeń,

- Wykonanie eksperymentu napawania,

- Pomiar wielkości wyjściowych,

- Statystyczne opracowanie wyników badań.

\section{Identyfikacja głównych parametrów procesu}

$\mathrm{Na}$ podstawie analizy literaturowej oraz wcześniej prowadzonych badań własnych [22:24] ustalono parametry napawania plazmowego (czynniki wejściowe) oraz ich zakresy istotnie wpływające na formowanie się i geometrię powłok (tabela II).

Tablica II. Istotne parametry napawania plazmowego i zakresy ich zmienności

Table II. Essential plasma surfacing parameters and the ranges of their changes

\begin{tabular}{|c|c|}
\hline Parametr & zakres zmienności \\
\hline Natężenie prądu łuku głównego [A] & $70-110$ \\
\hline Prędkość napawania [mm/min] & $50-70$ \\
\hline Wydatek proszku [g/min] & 6 - 8 \\
\hline Temperatura wstępnego podgrzania $\left(250^{\circ} \mathrm{C}\right)$ & nie - tak \\
\hline Oscylacja plazmotronu 450 [mm/min] & nie - tak \\
\hline Wydatek gazu plazmotwórczego [l/min] & $1,5-2$ \\
\hline $\begin{array}{c}\text { Odległość palnika od napawanej } \\
\text { powierzchni [mm] }\end{array}$ & $15-20$ \\
\hline
\end{tabular}

Pozostałe parametry procesu napawania były ustalone na stałym poziomie i niezmieniane $\mathrm{w}$ trakcie napawania. Do ważniejszych z nich należy zaliczyć:

- Natężenie prądu łuku wewnętrznego - 40A,

- Wydatek gazu osłonowego - $16 \mathrm{l} / \mathrm{min}$,

- Wydatek gazu transportującego proszek - $8 \mathrm{l} / \mathrm{min}$,

- Średnica dyszy zwężającej - $3 \mathrm{~mm}$,

- Amplituda oscylacji - $8 \mathrm{~mm}$.

\section{Wybór planu eksperymentu}

Na podstawie studium literaturowego, spośród planów przeznaczonych do badania istotności wpływu, wybrano plan Placketta-Burmana, na podstawie którego sporządzono matrycę doświadczenia. Plan ten m.in. umożliwia zbadanie istotności wpływu siedmiu czynników wejściowych na dwóch poziomach zmienności, oznaczonych odpowiednio znakami: plus - poziom górny i minus - poziom dolny, przy czym znaki te mogą oznaczać zarówno konkretne wartości liczbowe, istnienie lub brak danego czynnika, dobry lub zły jego stan oraz wartość logiczną "tak" lub „nie”. Z uwagi na powyższe, plan ten jest szczególnie przydatny w inżynierii spajania, gdzie oprócz konkretnych wartości liczbowych występują również inne, np.: podgrzanie materiału lub nie, biegunowość dodatnia lub ujemna, dodatkowe spoiwo lub nie.

\section{Opracowanie matrycy doświadczeń}

Plan Placketta-Burmana zakłada wykonanie liczby doświadczeń $\mathrm{N}=4 \mathrm{c}$, gdzie c jest liczbą całkowitą. Za pomocą tego planu możliwa jest ocena istotności wpływu n = 4c-1 badanych czynników na wielkość wynikową. Jeśli liczba czynników wejściowych przyjętych do badań jest mniejsza niż 4c-1, wówczas matrycę doświadczenia uzupełnia się o tzw. czynniki fikcyjne. W tym eksperymencie przyjęto $c=2$, toteż liczba doświadczeń wyniosła 8. Jednocześnie możliwe było zbadanie siedmiu czynników wejściowych, a więc tyle, ile przyjęto do eksperymentu (tabela II) i nie było potrzeby wprowadzania dodatkowych czynników fikcyjnych. Matrycę planu Placketta-Burmana dla $\mathrm{N}=8$ przedstawiono w tabeli III. Po wykonaniu doświadczenia kolumna y uzupełniana jest wynikami pomiarów czynnika wyjściowego. Następnie losowo przyporządkowano kolejność występowania poszczególnych zmiennych $\mathrm{x}$ i przyjęto poziomy zmienności: górny (+) i dolny (-) - tabela IV.

\section{Wykonanie eksperymentu napawania}

Próby napawania plazmowego prowadzono przy użyciu urządzenia PTA 301 Control M firmy Hettiger Stellite GmbH. Napoiny wykonano zgodnie z parametrami zamieszczonymi w tabeli IV. Długość napoin wynosiła ok $120 \mathrm{~mm}$.

Tablica III. Matryca Planu Placketta-Burmana dla $N=8$, wg. [10] Table III. Matrix of Plackett-Burman plan for $N=8$, acc. [10]

\begin{tabular}{|c|c|c|c|c|c|c|c|c|}
\hline $\mathrm{N}$ & $\mathrm{x}_{1}$ & $\mathrm{x}_{2}$ & $\mathrm{x}_{3}$ & $\mathrm{x}_{4}$ & $\mathrm{x}_{5}$ & $\mathrm{x}_{6}$ & $\mathrm{x}_{7}$ & $\mathrm{y}$ \\
\hline 1 & + & - & - & + & - & + & + & $\mathrm{y}_{1}$ \\
\hline 2 & + & + & - & - & + & - & + & $\mathrm{y}_{2}$ \\
\hline 3 & + & + & + & - & - & + & - & $\mathrm{y}_{3}$ \\
\hline 4 & - & + & + & + & - & - & + & $\mathrm{y}_{4}$ \\
\hline 5 & + & - & + & + & + & - & - & $\mathrm{y}_{5}$ \\
\hline 6 & - & + & - & + & + & + & - & $\mathrm{y}_{6}$ \\
\hline 7 & - & - & + & - & + & + & + & $\mathrm{y}_{7}$ \\
\hline 8 & - & - & - & - & - & - & - & $\mathrm{y}_{8}$ \\
\hline
\end{tabular}


Tablica IV. Oznaczenia i kolejność zmiennych oraz ich wartości na poziomie górnym i dolnym Table IV. The marks and order of variables with their values at the top and bottom levels

\begin{tabular}{|c|c|c|c|c|c|c|c|}
\hline $\mathrm{N}$ & $\begin{array}{c}\text { Natężenie } \\
\text { prądu } \\
\text { [A] }\end{array}$ & $\begin{array}{c}\text { Oscylacja } \\
\text { plazmotronu }\end{array}$ & $\begin{array}{l}\text { Prędkość } \\
\text { napawania } \\
\text { [mm/min] }\end{array}$ & $\begin{array}{c}\text { Odległość } \\
\text { palnika } \\
\text { od powierzchni } \\
\text { napawanej } \\
\text { [mm] }\end{array}$ & $\begin{array}{c}\text { Wydatek gazu } \\
\text { plazmowego } \\
\text { [l/min] }\end{array}$ & $\begin{array}{l}\text { Wydatek } \\
\text { proszku } \\
\text { [g/min] }\end{array}$ & $\begin{array}{c}\text { Podgrzewanie } \\
\text { wstępne }\end{array}$ \\
\hline 1 & 110 & nie & 50 & 20 & 1,5 & 8 & tak \\
\hline 2 & 110 & tak & 50 & 15 & 2 & 6 & tak \\
\hline 3 & 110 & tak & 70 & 15 & 1,5 & 8 & nie \\
\hline 4 & 70 & tak & 70 & 20 & 1,5 & 6 & tak \\
\hline 5 & 110 & nie & 70 & 20 & 2 & 6 & nie \\
\hline 6 & 70 & tak & 50 & 20 & 2 & 8 & nie \\
\hline 7 & 70 & nie & 70 & 15 & 2 & 8 & tak \\
\hline 8 & 70 & nie & 70 & 15 & 1,5 & 6 & nie \\
\hline
\end{tabular}

\section{Pomiar wielkości wyjściowych}

Jako wielkości wyjściowe przyjęto wymiary charakteryzujące geometrię napoiny, zgodnie z rysunkiem 1:

- wysokość nadlewu a,

- szerokość lica b,

- głębokość wtopienia c = x - a,

- udział materiału podłoża w napoinie D wyznaczany ze wzoru $\mathrm{D}=\mathrm{B} / \mathrm{A}+\mathrm{B} \times 100 \%$.

Wykonanie pomiarów wielkości geometrycznych napoin wymagało przygotowania odpowiednich próbek do badań metalograficznych makroskopowych. W tym celu, dla zapewnienia poprawności wnioskowania, wszystkie próbki przecięto w stałej odległości $(70 \mathrm{~mm})$ od początku ściegu. Cięcie prowadzono za pomocą piły taśmowej intensywnie chłodzonej. Następnie próbki poddano szlifowaniu i trawieniu za pomocą nitalu. Na rysunku 2 przedstawiono widok tak przygotowanych próbek do pomiarów geometrycznych. Zauważalny jest wyraźnie różny kształt napoin.

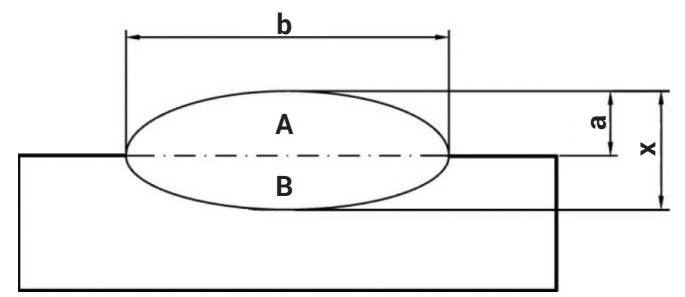

Rys. 1. Schemat charakterystycznych wymiarów geometrycznych napoiny Fig. 1. Diagram of the characteristic geometric dimensions of the weld overlays

Tablica V. Wyniki pomiaru geometrii napoin

Table $\mathbf{V}$. The results of geometry measurement of welds overlays

\begin{tabular}{|c|c|c|c|c|}
\hline $\mathrm{N}$ & $\begin{array}{c}\text { Wysokość } \\
\text { napoiny a } \\
{[\mathrm{mm}]}\end{array}$ & $\begin{array}{c}\text { Szerokość } \\
\text { napoiny b } \\
{[\mathrm{mm}]}\end{array}$ & $\begin{array}{c}\text { Głębokość } \\
\text { wtopienia c } \\
{[\mathrm{mm}]}\end{array}$ & $\begin{array}{c}\text { Współczynnik } \\
\text { wymieszania } \\
\mathrm{D}[\%]\end{array}$ \\
\hline 1 & 2,58 & 14,14 & 0,87 & 29,27 \\
\hline 2 & 1,92 & 15,10 & 1,51 & 43,23 \\
\hline 3 & 1,81 & 14,23 & 0,77 & 32,35 \\
\hline 4 & 1,69 & 12,55 & 0,14 & 5,46 \\
\hline 5 & 1,87 & 9,09 & 1,32 & 39,11 \\
\hline 6 & 2,18 & 16,57 & 1,21 & 26,65 \\
\hline 7 & 2,84 & 8,59 & 0,33 & 7,34 \\
\hline 8 & 2,39 & 9,83 & 0,72 & 11,97 \\
\hline
\end{tabular}
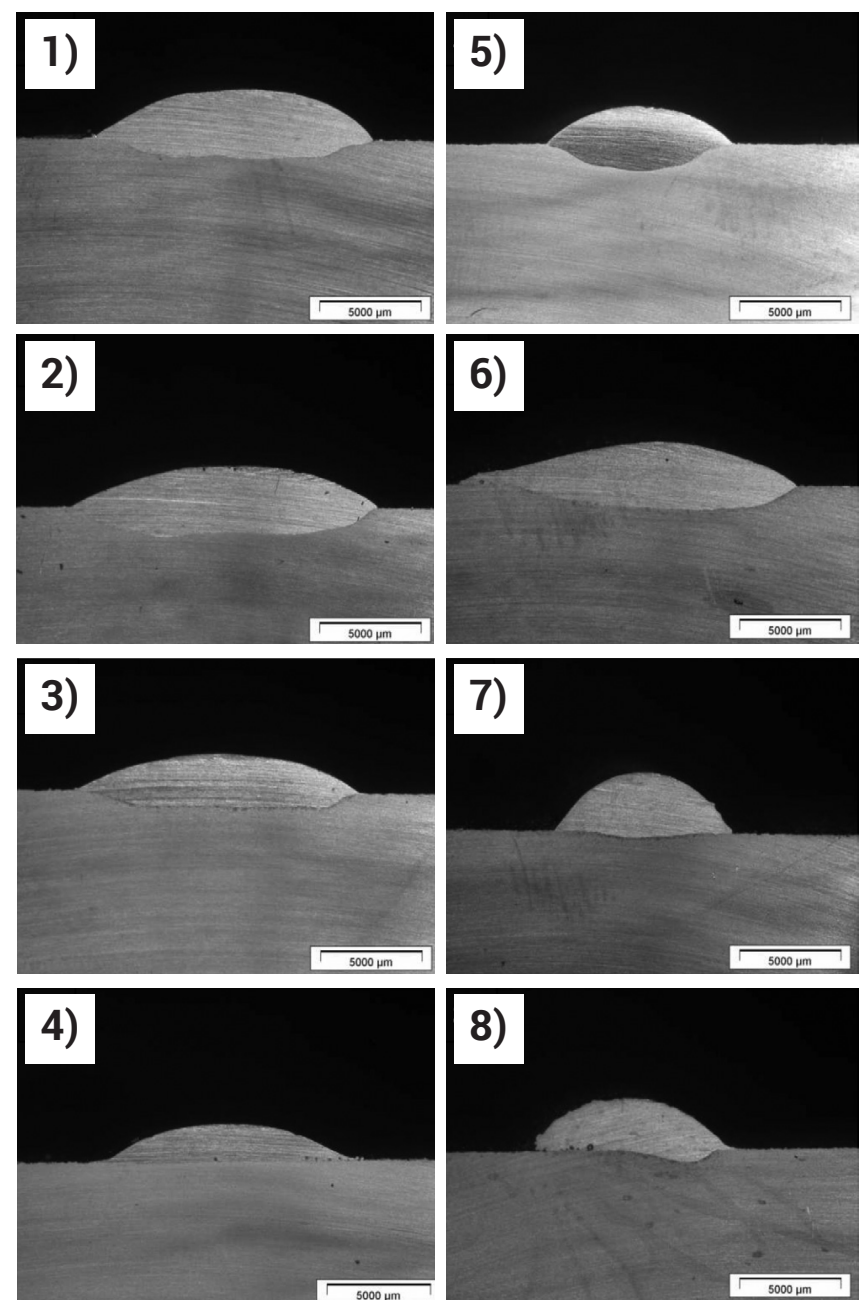

Rys. 2. Makrostruktury napoin

Fig. 2. The macrostructures of the welds overlays

Pomiary prowadzono na stanowisku wyposażonym w wysokiej klasy mikroskop optyczny z cyfrową rejestracją obrazu. Zdjęcia przekazywane były do stanowiska komputerowego, a odpowiednie wymiary wyznaczano za pomocą programu do analizy obrazów metalograficznych analysIS. W tabeli V przedstawiono wyniki tych badań.

\section{Statystyczne opracowanie wyników badań}

Brak zmiennych fikcyjnych w matrycy doświadczenia uniemożliwia wykonanie opracowania statystycznego 
wyników badań na podstawie programu Placketta-Burmana. W związku z powyższym opracowanie to wykonano na podstawie programu bilansu losowego. Wg [10] procedura określenia istotności czynników wejściowych na czynnik wynikowy zakłada obliczenie median dla poziomu wyższego i niższego dla każdego badanego czynnika, a następnie różnicę tych median. Największy wpływ na czynnik wynikowy ma ten czynnik, dla którego różnica median jest największa. Następnie dokonuje się korekty wyników dla pozostałych czynników wejściowych. Korekta ta polega na tym, że od wszystkich wyników pomiarów na poziomie górnym odejmuje się różnicę median czynnika istotnego. Działanie to eliminuje oddziaływanie czynnika najbardziej istotnego na inne wyniki pomiarów. Po korekcie ponownie obliczana jest różnica median i wyłaniany jest kolejny istotny czynnik. Procedura ta powtarzana jest do chwili, w której kolejny czynnik zostanie uznany za nieistotnie wpływający na czynnik wynikowy lub do wyłonienia trzech najistotniejszych czynników.

Stosownie do otrzymanych wyników wysokości napoiny (tabela $\mathrm{VI}$ ) obliczono mediany dla poziomu wyższego i niższego oraz różnicę tych median - tabela VII. Na rysunku 3 przedstawiono wykres rozrzutu dla wszystkich wyników, w którym na osi odciętych odłożono czynniki wejściowe wraz z ich poziomami a na osi rzędnych wartości czynnika wynikowego wraz z medianami. Różnicę median zobrazowano na wykresie przy pomocy strzałek. Graficzną wizualizację różnicy median przedstawiono na rysunku 4.

Z rysunku 4 wynika, że najistotniejszy wpływ na wysokość napoin ma oscylacja plazmotronu. Im większa amplituda oscylacji tym mniejsza wysokość napawanej warstwy, ponieważ materiał dodatkowy rozmieszczany jest na większej powierzchni. W celu określenia kolejnych parametrów istotnie wpływających na czynnik wynikowy dokonano korekty wyników wyłączając parametr najistotniejszy. Od wszystkich wyników pomiarów na poziomie górnym odjęto wartość różnicy median czynnika najbardziej istotnego, a następnie ponownie obliczano mediany oraz ich różnice.

Tablica VI. Macierz planowania i wyniki obliczeń wysokość napoiny Table VI. The design matrix and results of calculations of heights of the weld overlays

\begin{tabular}{|c|c|c|c|c|c|c|c|c|c|c|}
\hline $\mathrm{N}$ & $\mathrm{x}_{1}$ & $\mathrm{x}_{2}$ & $\mathrm{x}_{3}$ & $\mathrm{x}_{4}$ & $\mathrm{x}_{5}$ & $\mathrm{x}_{6}$ & $\mathrm{x}_{7}$ & $\mathrm{y}$ & $\mathrm{y}_{\mathrm{kor} 1}$ & $\mathrm{y}_{\mathrm{kor} 2}$ \\
\hline 1 & + & - & - & + & - & + & + & 2,58 & 2,58 & 2,24 \\
\hline 2 & + & + & - & - & + & - & + & 1,92 & 2,54 & 1,30 \\
\hline 3 & + & + & + & - & - & + & - & 1,81 & 2,43 & 2,09 \\
\hline 4 & - & + & + & + & - & - & + & 1,69 & 2,31 & 1,07 \\
\hline 5 & + & - & + & + & + & - & - & 1,87 & 1,87 & 1,87 \\
\hline 6 & - & + & - & + & + & + & - & 2,18 & 2,80 & 2,46 \\
\hline 7 & - & - & + & - & + & + & + & 2,84 & 2,84 & 2,50 \\
\hline 8 & - & - & - & - & - & - & - & 2,39 & 2,39 & 2,39 \\
\hline
\end{tabular}

Tablica VII. Mediany i ich różnice dla wartości wysokość napoiny Table VII. Medians and their differences of the height of the weld overlays

\begin{tabular}{|c|c|c|c|c|c|c|c|}
\hline Czynnik & $x_{1}$ & $x_{2}$ & $x_{3}$ & $x_{4}$ & $x_{5}$ & $x_{6}$ & $x_{7}$ \\
\hline Poziom górny (+) & 1,90 & 1,87 & 1,84 & 2,03 & 2,05 & 2,38 & 2,25 \\
\hline Poziom dolny (-) & 2,29 & 2,49 & 2,29 & 2,16 & 2,10 & 1,90 & 2,03 \\
\hline Różnica & $-0,39$ & $-0,62$ & $-0,45$ & $-0,13$ & $-0,05$ & 0,49 & 0,23 \\
\hline
\end{tabular}

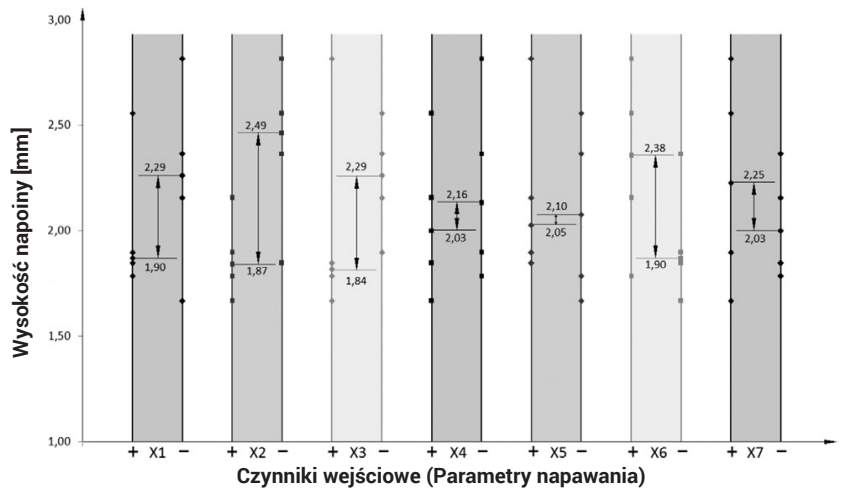

Rys. 3. Wykres rozrzytu wyników

Fig. 3. A scatterplot of the experiment results

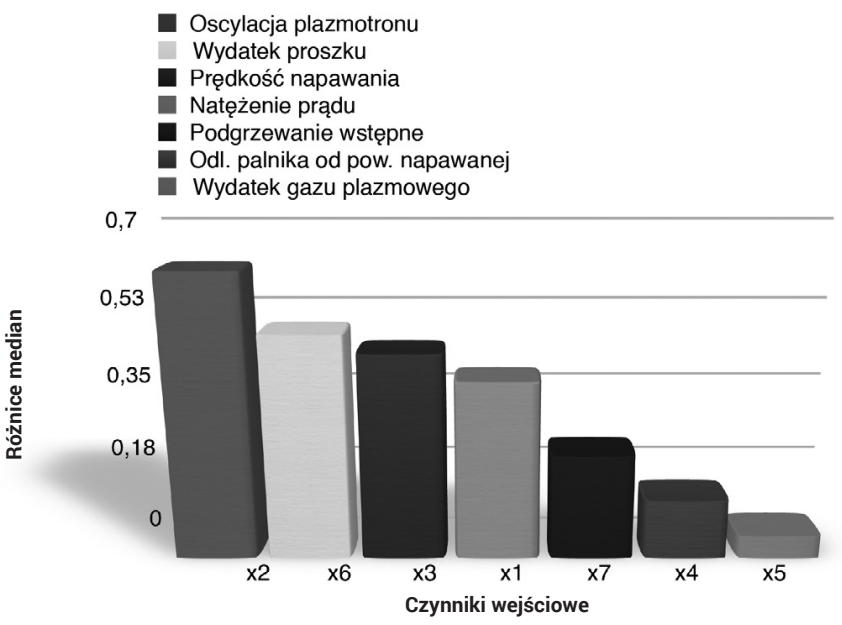

Rys. 4. Różnice median czynników wejściowych dla wysokości napoin Fig. 4. The median differences of input factors for heights of weld overlays

Skorygowane dane zamieszczono w tabeli VI w kolumnie $\mathrm{y}_{\text {korr. }}$. Wartości median oraz ich różnic po pierwszej korekcie przedstawiono w tabeli VIII. Po korekcie wyników widać, iż kolejnym parametrem istotnie wpływającym na wysokość napoin jest wydatek proszku $\left(\mathrm{x}_{6}\right)$. Wzrost ilości podawanego proszku skutkuje zwiększeniem grubości napawanego ściegu. Następnie w analogiczny sposób przeprowadzono drugą korektę. Skorygowane dane uzupełniono w tabeli VI w kolumnie $\mathrm{y}_{\mathrm{kor} 2}$ natomiast wartości median i ich różnice

Tablica VIII. Mediany i ich różnice dla wartości wysokość napoin po pierwszej korekcie

Table VIII. Medians and their differences for the heights of the weld overlays after the first correction

\begin{tabular}{|c|c|c|c|c|c|c|c|}
\hline Czynnik & $x_{1}$ & $x_{2}$ & $x_{3}$ & $x_{4}$ & $x_{5}$ & $x_{6}$ & $x_{7}$ \\
\hline Poziom górny (+) & 2,49 & \multirow{3}{*}{-} & 2,37 & 2,45 & 2,67 & 2,69 & 2,56 \\
\cline { 1 - 5 } Poziom dolny (-) & 2,62 & - & 2,56 & 2,49 & 2,41 & 2,35 & 2,41 \\
\cline { 1 - 5 } Różnica & $-0,13$ & & $-0,19$ & $-0,04$ & 0,23 & 0,34 & 0,15 \\
\hline
\end{tabular}

Tablica IX. Mediany i różnice median dla wartości wysokość napoin po drugiej korekcie

Table IX. Medians and their differences for the heights of the weld overlays after the second correction

\begin{tabular}{|c|c|c|c|c|c|c|c|}
\hline Czynnik & $x_{1}$ & $x_{2}$ & $x_{3}$ & $x_{4}$ & $x_{5}$ & $x_{6}$ & $x_{7}$ \\
\hline Poziom górny (+) & 1,98 & \multirow{3}{*}{ - } & 1,98 & 2,06 & 2,17 & \multirow{3}{*}{ - } & 1,77 \\
\hline Poziom dolny (-) & 2,43 & & 2,32 & 2,24 & 2,17 & & 2,23 \\
\hline Różnica & $-0,45$ & & $-0,34$ & $-0,18$ & 0,00 & & $-0,46$ \\
\hline
\end{tabular}


po drugiej korekcie zamieszczono w tabeli IX. Z otrzymanych danych wynika, iż kolejnym parametrem istotnie wpływającym na wysokość napawanego ściegu jest temperatura wstępnego podgrzewania $\left(\mathrm{x}_{7}\right)$. Zastosowanie wstępnego podgrzewania materiału przed napawaniem prowadzi do intensywniejszego nadtopienia podłoża, wzrostu szerokości napoiny, a to z kolei skutkuje zmniejszeniem grubości powłoki.

Analogicznie do powyższego przykładu przeprowadzono statystyczne opracowanie pozostałych wyników ekspery-

Tablica X. Istotność wpływu parametrów napawania na wymiary geometryczne napoin

Table X. The significance of the impact of surfacing parameters on geometrical dimensions of weld overlays

\begin{tabular}{|c|c|c|c|}
\hline $\begin{array}{c}\text { Istotność } \\
\text { parametrów }\end{array}$ & $\begin{array}{c}\text { Szerokość } \\
\text { napoiny b } \\
{[\mathrm{mm}]}\end{array}$ & $\begin{array}{c}\text { Głębokość } \\
\text { wtopienia c } \\
{[\mathrm{mm}]}\end{array}$ & $\begin{array}{c}\text { Współczynnik } \\
\text { wymieszania D } \\
{[\%]}\end{array}$ \\
\hline 1 & $\begin{array}{c}\text { Oscylacja } \\
\text { plazmotronu }\end{array}$ & $\begin{array}{c}\text { Natężenie } \\
\text { prądu }\end{array}$ & Natężenie prądu \\
\hline 2 & $\begin{array}{c}\text { Prędkość } \\
\text { napawania }\end{array}$ & $\begin{array}{c}\text { Wydatek } \\
\text { gazu } \\
\text { plazmowego }\end{array}$ & $\begin{array}{c}\text { Wydatek gazu } \\
\text { plazmowego }\end{array}$ \\
\hline 3 & $\begin{array}{c}\text { Wydatek } \\
\text { proszku }\end{array}$ & $\begin{array}{c}\text { Prędkość } \\
\text { napawania }\end{array}$ & $\begin{array}{c}\text { Prędkość } \\
\text { napawania }\end{array}$ \\
\hline
\end{tabular}

mentu i wyłoniono parametry istotnie wpływające na szerokość napoin, głębokość wtopienia oraz udział metalu podłoża w napoinie (tabela $\mathrm{X}$ ).

Głównym parametrem wpływającym na wzrost szerokości napoin jest zastosowanie lub nie ruchu oscylacyjnego. Od wielkości amplitudy oscylacji plazmotronu zależy szerokość napawanego ściegu. Drugim istotnym czynnikiem jest prędkość napawania, im jest mniejsza, tym większa jest szerokość powłoki, ponieważ zwiększa się energia liniowa napawania, skutkując intensywniejszym rozpływaniem się ciekłego metalu. Kolejnym istotnym parametrem jest wydatek proszku. Wzrost ilości podawanego materiału dodatkowego zwiększa szerokość napoiny.

Głębokość wtopienia oraz udział metalu podłoża w napoinie zależą od tych samych parametrów uszeregowanych w tej samej kolejności. Najistotniejszym czynnikiem jest natężenie prądu, im jest większe tym bardziej zwiększa się energia liniowa procesu napawania, co powoduje jednocześnie wzrost nadtopienia materiału podłoża i jego udziału w napoinie. Ten sam efekt powoduje wzrost wydatku gazu plazmowego. Wówczas zwiększa się energia cieplna strumienia plazmy. Trzecim ważnym parametrem jest prędkość napawania. Im jest mniejsza, tym zwiększa się energia liniowa napawania, a więc również głębokość wtopienia w materiał podłoża i jego udział w napoinie powiększają się.

\section{Podsumowanie}

Na podstawie przeprowadzonych badań ustalono, które z parametrów procesu istotnie wpływają na wymiary geometryczne napoin. Wykazano, iż badane czynniki wyjściowe (wymiary napoin) na ogół zależą od różnych grup parametrów. W praktyce jednak przeważnie steruje się parametrami mającymi wpływ na poziom energii liniowej, co nie zawsze jest podejściem odpowiednim. Toteż wyniki te mogą stanowić ważne źródło informacji dla projektowania procesów technologicznych napawania plazmowego.

Powyższe wnioski wyciągnięto na podstawie badań przy wykorzystaniu statystycznych metod planowania eksperymentu. Adaptacja tych narzędzi znacząco ułatwia analizę wyników i ogranicza liczbę prób, a tym samym zmniejsza nakłady finansowe, pracochłonność i czas badań.

\section{Literatura}

[1] Deuis R.L., Yellup J.M., Subramanian C.: „Metal-matrix composite coatings by PTA surfacing". Composite Science \& Technology, 58, 1998, 299-309.

[2] Liu Y. F., Xia Z. Y., Han J. M., Zhang G. L., Yang S. Z.: „Microstructure and wear behavior of $(\mathrm{Cr}, \mathrm{Fe}) 7 \mathrm{C} 3$ reinforced composite coating produced by plasma transferred arc weld-surfacing process", Surface \& Coatings Technology, 2006, No 201, $863-867$.

[3] Liyanage T., Fisher G., Gerlich A.P.: „Microstructures and abrasive wear performance of PTAW deposited Ni-WC overlays using different Ni-alloy chemistries", Wear, 2012, No 274-245, 345-354.

[4] Jitai N., Wei G., Mianhuan G., Shixiong L.: „Plasma application in thermal processing of materials", Vacuum 65, 2002, 263- 266.

[5] Weroński A., Gardyński J.: „Nakładanie powłok metodą plazmową na części samochodowe", Przegląd Spawalnictwa nr 1 - 2, 1996, 14 - 16.

[6] Weroński A., Pałka K.: „Zwiększenie trwałości nurników homogenizatorów przez napawanie plazmowe", Przegląd Spawalnictwa nr 1 - 2, 1996, 20 - 22.

[7] Klimpel A., Górka J., Czupryński A.: „Napawanie proszkowe PTA warstw wierzchnich suwaka zasuwy urządzeń naftowych", Przegląd Spawalnictwa nr 5 - 6, 2006, $15-19$

[8] Górak J., Czupryński A., Kik T., Melcer M.: „Przemysłowe aplikacje napawania plazmowego proszkowego", Przegląd Spawalnictwa $\mathrm{nr}$ 9, 2011, 87-94.

[9] Polański Z.: Planowanie doświadczeń w technice, PWN, Warszawa 1984

[10] Korzyński M.: Metodyka eksperymentu, WNT, Warszawa 2006.

[11] Kukiełka L.: Podstawy badań inżynierskich, PWN, Warszawa 2002.

[12] Zając A., Kubiszyn I.: Analiza procesu napawania drutem proszkowym samoosłonowym Lincore 50 przy zastosowaniu metody planowania eksperymentu, Biuletyn Instytutu Spawalnictwa No 4, 1993, 35-39.

[13] Fydyrch D., Rogalski G.: Wpływ warunków spawania podwodnego metodą lokalnej komory suchej na zawartość wodoru dyfundującego w stopiwie, Przegląd Spawalnictwa No 11, 2009, 29-34.

[14] Fydrych D., Sommer S., Rogaski G.: Wspomaganie decyzji zakupu urządzeń do spawania metodą MIG/MAG z wykorzystaniem analizy skupień, Przegląd Spawalnictwa No 12, 2014, 26-33.
[15] Bęczkowski R., Gucwa M.: Statystyczna ocena wpływu parametrów napawania SSA na geometrię napoin, Przegląd Spawalnictwa No 10 , 2011, 40-43.

[16] Balasubramanian V., Varahamoorthy R., Ramachandran C.S., Babu S.: Abrasive slurry wear behavior of stainless steel surface produced by plasma transferred arc hardfacing process, Surface \& Coatings Technology, 202, 2008, 3903-3912.

[17] Ramachandran C.S., Balasubramanian V., Varahamoorthy R.: Comparative evaluation of dry sliding wear behaviour of plasma transferred arc hardfaced surfaces by the pin-on-roller method, Proc. IMechE Vol. 224 Part J: J. Engineering Tribology, 2010, 91-106.

[18] Siva K., Murugan N., Raghupathy V.P.: Modelling, analysis and optimisation of weld bead parameters of nickel based overlay deposited by plasma transferred arc surfacing, Archives of Computational Materials Science and Surface Engineering, vol. 1, 2009, 174-182.

[19] Siva K., Murugan N., Logesh R.: Optimization of weld bead geometry in plasma transferred arc hardfaced austenitic stainless steel plates using genetic algorithm, Int J Adv Manuf Technol, vol. 41, 2009, 24-30.

[20] Lakshminarayanan A. K., Balasubramanian V., Varahamoorthy R., Babu S.: Predicting the Dilution of Plasma Transferred Arc Hardfacing of Stellite on Carbon Steel Using Response Surface Methodology, METALS AND MATERIALS International, Vol. 14, No. 6, 2008, 779-789.

[21] Tobota K.: Wpływ podstawowych parametrów napwania plazmowego na geometrię napoin, Praca Dypl. Inż., Zakład Inżynierii Spajania PW Warszawa 2014

[22] Klimpel A.: Technologie napawania i natryskiwania cieplnego, wyd. Pol. Śląska, Gliwice 1999.

[23] Bober M., Senkara J.: Wpływ podstawowych parametrów napawania plazmowego na udział metalu podłoża w napoinie kompozytowej; Sympozjum Katedr i Zakładów Spawalnictwa, Gliwice, 10.X.2003r, Materiały konferencyjne, $51-60$.

[24] Bober M., Senkara J.: Formowanie się napoin na bazie niklu z węglikami metali przejściowych, Biuletyn Instytutu Spawalnictwa, nr 5/2010, rocznik 54, $103-107$ 